\title{
LAS ELECCIONES ARGENTINAS DE 1983
}

El 30 de octubre Argentina vivió una jornada electoral largamente esperada que dio al pueblo argentino la posibilidad de escapar a la Junta Militar que había regido los destinos del país durante los últimos años, desde que, en 1976, el general Videla tomara el poder, entonces en manos de María Estela Martínez de Perón.

Estas elecciones suponían el retorno de la política argentina a unas coordenadas de aspiración democrática y participación popular y suponían, también, el contacto de los partidos políticos argentinos de hoy con sus votantes. $\mathrm{Y}$ este encuentro ha sido significativamente negativo para el peronismo -Partido Justicialista-, que se ha visto superado en su deseo de alcanzar la Presidencia de la República por la Unión Cívica Radical. Italo Lúder, líder peronista, fue derrotado ampliamente por el candidato de la Unión Cívica Radical, Raúl Alfonsín.

No se puede negar que algunos votantes «peronistas», cambiando su voto teórico, han acabado otorgando su confianza al partido Unión Cívica Radical, quizá con la esperanza de ser gobernados con más acierto de lo que lo fueron bajo el mandato peronista inmediatamente anterior a la toma del poder por los militares argentinos.

Toda vez que el sufragio fue obligatorio en estas elecciones, no es posible una interpretación crítica sobre el índice de participación, que en esta ocasión alcanzó el 82 por 100, mientras que los votos en blanco suponían el 2 por 100 y los votos nulos el 0,70 por 100 .

Como dato anecdótico señalaremos que los hombres y las mujeres votaron en mesas electorales diferentes y presididas por ciudadanos de su sexo correspondiente, como consecuencia de la existencia en Ârgentina de dos padrones diferentes, uno masculino y otro femenino.

Como es sabido, el sistema para la elección del Presidente de la República Argentina es indirecto y éste es elegido por la mitad más uno, al menos, de los 600 electores, elegidos, a su vez, por los votantes. El candidato a la Presidencia de la República por la Unión Cívica Radical, Raúl Alfonsín, ha sido elegido por el voto afirmativo de 337 electores, lo que supone que a los de su propio partido se han unido 20 electores ajenos a la Unión Cívica Radical.

Los resultados generales de estas elecciones argentinas han sido los siguientes: 


\section{RESULTADOS FINALES}

\begin{tabular}{|c|c|c|c|c|c|c|}
\hline & $\begin{array}{l}\text { Presidente } \\
\text { (votos) }\end{array}$ & $\%$ & Electores & $\begin{array}{c}\text { Goberna- } \\
\text { dores }\end{array}$ & Diputados & Senadores \\
\hline Unión Cívica Radical & 7.659 .530 & 50,50 & 317 & 9 & 129 & 16 \\
\hline Partido Justicialista $\ldots \ldots \ldots$ & 5.936 .556 & 39,00 & 259 & 12 & 111 & 24 \\
\hline $\begin{array}{l}\text { Partido Intransigente .... ... } \\
\text { Movimiento de Integración y }\end{array}$ & 344.434 & 2,26 & 2 & - & 3 & - \\
\hline $\begin{array}{ccccc}\text { Desarrollo } & \ldots & \ldots & \ldots & \ldots\end{array}$ & 179.589 & 1,18 & 2 & - & 一 & - \\
\hline Alianza Federal $\ldots \ldots \ldots \ldots$ & 56.506 & 0,40 & - & 一 & - & - \\
\hline Otros partidos nacionales ... & 572.504 & 4,00 & - & - & 1 & - \\
\hline Otros partidos provinciales ... & 400.063 & 2,80 & 20 & 3 & 10 & 6 \\
\hline
\end{tabular}

FUENTE: Datos aportados por la Embajada de Argentina en Madrid.

Yolanda GÓmeZ SáNCHeZ 